INDONESIAN JOURNAL OF APPLIED LINGUISTICS

Vol. 10 No. 1, May 2020, pp. 95-106

Available online at:

https://ejournal.upi.edu/index.php/IJAL/article/view/24993

https://doi.org/10.17509/ijal.v10i1.24993

\title{
A corpus-based lexical analysis of Indonesian English as a new variety
}

\author{
Ignatius Tri Endarto \\ English Language Education Department, Universitas Kristen Duta Wacana, \\ $\mathrm{Jl}$. dr. Wahidin Sudirohusodo 5-25, Yogyakarta, Indonesia
}

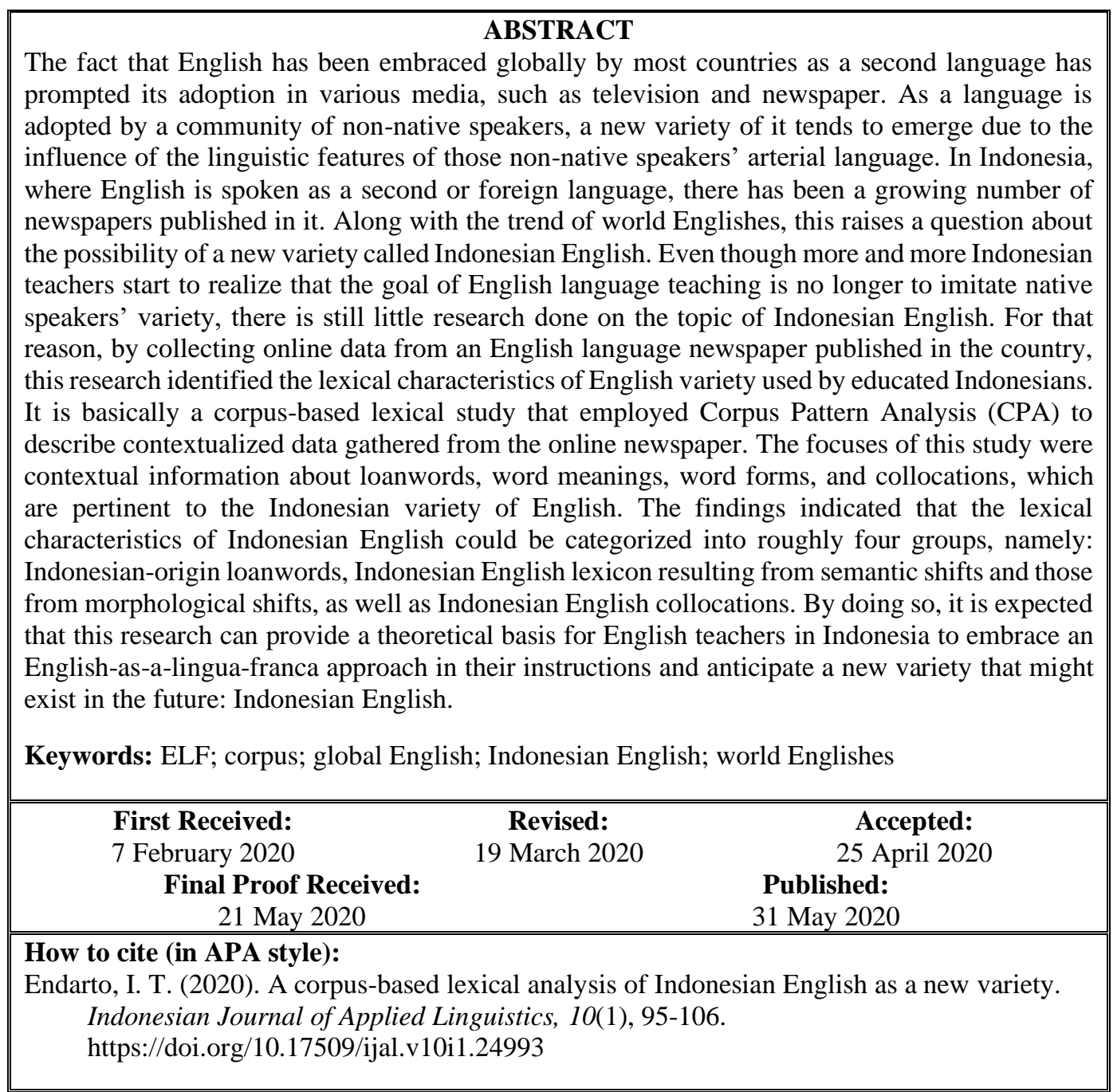

\section{INTRODUCTION}

Indonesia is a home for various languages, dialects, and cultures (Asimonoff, 2014). Living in such a multilingual setting, Indonesians recognize three main groups of languages, namely national, local/vernacular, and foreign languages (Alwi \& Sugono, 2011). Although English in this case is still regarded by most people as a foreign tongue, it has actually outpaced the others in terms of its number of learners and how it is used in the country. In Indonesia, English has become the most renowned and widely learned international language (Lauder, 2008).

Vis-à-vis its status as a massively learned international language, by the time English was embraced by speakers of other languages it no longer acted as an exclusive communication tool limited only for the native speakers. Anthropologically speaking, when the language went global, it was not seen as being tied to only one culture like it used to be. Stockton (2018, p. 133) regards this phenomenon as part of languacultures. He states that as English becomes various Englishes, it is adjusted to adopt the 
new cultures it interacts with. Such a situation has created varieties of English that we know today, like Indian English, Singaporean English, and many others. In the case of English-as-a-foreign-language (EFL) countries, like Indonesia, there are certainly different types of Englishes spoken, though they are not generally considered or standardized to be new varieties. It is indicated by the growing number of studies on world Englishes which discuss EFL as part of their analyses (Rautionaho et al., 2018). Kirkpatrick (2007) points out that the distinction between EFL and English as a second language (ESL) has actually blurred due to the increasing role of the language in EFL countries. If this is true then, besides Indian English and Singaporean English, there are also EFL varieties like Chinese English, Japanese English, and of course Indonesian English.

In Indonesia, people's views on the use of English have changed quite a couple of times throughout history. There was a time when the use of English was seen as a form of linguistic imperialism, resulting in some sort of deterrence against it (Lie, 2017). Some opposing views on the other hand consider English a non-interfering factor toward nationalism and the development of Indonesian as the national language (Dardjowidjojo, 2003; Lie, 2017). Instead of depicting English as the language of a foreign culture, those views perceive it to be an enabling tool which facilitates global communication (Lauder 2008; Stockton, 2018).

Regarding Indonesian teachers' attitude toward English varieties, Zacharias (2005, cited in Stockton, 2018) in her survey finds that a majority of her research participants, who were English language teachers in Indonesia, favored international materials from English-speaking countries over those from Indonesia. It indicates that English was viewed by the teachers as merely the privilege of native speakers or those from "foreign" countries. As a result, the goal of English language teaching (ELT) perceived by those teachers was to simply imitate other speakers' register and culture rather than one's own identity. Such a goal has not taken into account the fact that an increasing number of Indonesians have started to use English much more frequently to communicate with each other on social media, various mass media, and other types of online platforms. In agreement with Stockton (2018, p. 146), the current ELT should be able to accommodate nationalist movements which give rise to several Englishes supporting English-asa-lingua-franca (ELF) approaches globally and in several EFL/ESL countries like Indonesia.

A notion that to some degree coheres with English-as-a-lingua-franca approaches is the idea of world Englishes posited by Kachru (1992). In his view, English speakers are not only the British or Americans, but also those who are considered nonnative speakers of the language synchronically or by history. In other words, English varieties are not merely British and American English, but also a large number of other Englishes which are used by ESL/EFL speakers. He then categorized Englishspeaking countries into largely three groups: countries where English is used as a mother tongue (the inner circle), countries where English becomes an official language and not a mother tongue (the outer circle), and countries where English is recognized as a foreign language (the expanding circle).

Among those three groups of English-speaking countries, Indonesia according to Kachru (1992) belongs to the last category where English is used as a foreign language. However, there are competing opinions which put countries like Indonesia in both outer and expanding circles at once as more and more people, especially from urban areas in the country, grow up speaking English as a second language (Endarto, 2018). If this trend persists, it is very likely that Indonesia will be a new English-speaking country in Asia along with its neighboring statesMalaysia, Singapore and the Philippines. Although some might argue that it is too early at the moment to categorize Indonesia as an outer-circle country, there is a very strong indication that it is already in transition toward that kind of status.

The quintessential change that has been happening in the country in the last decades is the increasing use of English in both spoken and written media. It is now very common to see youngsters or public figures incorporate English into their speech either in part or in its entirety, through codeswitching or code-mixing. It is also not unusual to find books, novels, newspapers, or any kinds of works written in English by Indonesian authors. A study conducted by Poblete et al. (2011) reveals that in Indonesia, English was the third most used language on Twitter, numbering more than $10 \%$ of the total tweets. In education, Indonesia ranked fifth among top 10 countries for the number of Englishmedium international schools (Civinini, 2019). Therefore, research on Indonesians' variety of English would neither be too impractical nor unfeasible to conduct since, as propounded by a number of scholars (Jenkins, 2000; Kachru \& Nelson, 2006; Kirkpatrick, 2012), both teachers and students need to realize that imitating American, British, or other "foreign" varieties of English may not always serve as an ideal and viable learning objective any longer.

Regardless of its debatable status as a second or foreign language, English has always been considered prestigious in Indonesia. Rini (2014) states that several factors contribute to this high status of English and the importance of learning it, including marketing purposes and job requirements. While people learn and use English at various proficiency levels, at the same time they create their own variety of the language which is shaped and influenced by their L1-Indonesian (Dewi et al., 2018, p. 28). A number of studies (Dewi et al., 2018; 
Gur, 2009; Muhammad, 2015) have scrutinized the use of this variety. However, instead of examining the English produced by Indonesians, they put a lot of emphasis on Indonesian language which contains English expressions.

In fact, considering the growing popularity of English as a lingua franca, the emergence of new varieties like Indonesian English is imminent. Berardo (2011) in his study has named a large number of cases where new dialects of English-which he calls new Englishes-emerged from various developmental backgrounds, such as Indian English, Kenyan English, Ghanaian English, Nigerian English, Caribbean English, and Papua New Guinea English. As Martin (2016) puts it, learners who do not get any exposure to English from an early age are very unlikely to achieve native-like proficiency and thus the English that they produce will pretty much be influenced by their L1 which in turn creates a new dialect. This is the case with Indonesian English. Despite being a dialect which has not been standardized, Indonesian English is present in actual communication among the people (Dewi et al., 2018, p. 28).

An example of media in Indonesia which uses English quite extensively is newspapers. Some of the Indonesian newspapers which are published in English and also available online are, for instance, The Jakarta Post, Jakarta Globe, The Bali Times, and Independent Observer. A large number of articles published in those newspapers are written by Indonesian authors and mostly talk about local issues or topics. Looking at those elements of register, specifically the tenor (authors/writers) and field (topics/subject matters), it seems that the English used in the articles is of Indonesian variety. The reason for that claim is due to the fact that English as a foreign language has been adopted by those Indonesian authors/writers to talk about local issues or topics which are pertinent to Indonesian contexts. As Crystal (cited in British Council Serbia, 2013) puts it, it does not take long for a new variety to emerge when English is adopted by other (ESL/EFL) speakers because adaptation will also start to occur as the language embraces various new words from those foreign contexts to reflect their underlying cultural backgrounds.

Since there is only a limited amount of research conducted into that Indonesian English variety, this study aims to scrutinize it via a corpus-based lexical analysis. Through compiling online data from one of English language newspapers published in the country, it seeks to identify the lexical characteristics of the written dialect produced by the authors. By doing so, it is expected that the findings of this study can lay the foundation for the linguistic descriptions of Indonesian English as a variety among other Englishes. For Indonesian context, this research is relevant because, as stated by Dewi et al. (2018, p. 33 , the need for standard Indonesian English is getting more imperative in the future as more and more people in the country use English. However, due to its descriptive nature, this research does not intend to standardize but rather to describe the lexical features found in the corpus which might distinguish the variety from other Englishes.

\section{METHOD}

This paper aims at scrutinizing the variety of English in Indonesia. It analyzes the written form of English in The Jakarta Post as one of Indonesia's online newspapers. This newspaper was chosen because it is a very popular English-language daily that talks about Indonesia-related topics. Moreover, it is published in Indonesia and, based on the researches' observation, it contains a considerable number of articles which either are written by Indonesians or at least talk about Indonesia-related topics such as national news, local health issues, Indonesian arts and culture, local attractions, foods, and many others.

The main focus of this research is the use of local lexicon in the newspaper articles which were published by the date of and accessed online on January 9, 2020. Those articles were on various topics and gathered in the corpus to be later selected and analyzed based on certain linguistic features or keywords indicative of Indonesian English.

This study employs a corpus-based lexical research design that uses Corpus Pattern Analysis (CPA) to describe the contextualized data gathered from the online newspaper. According to Hanks (2009), CPA is an analysis of identifying word meaning from its contextual use mirrored by its collocation and phraseological patterns. In that sense, the meaning of a word is not identified in isolation but, instead, inferred based on its prototypical use in the concordances.

First, corpus data were compiled in the form of electronic versions of newspaper articles collected from Google corpus (2013). After potential keywords were determined, queries with specific search operators from the "News" menu bar were carried out to retrieve and identify the number of relevant articles from The Jakarta Post. A hundred and forty articles were manually selected to represent the 35 keywords indicative of Indonesian English. The selection was done purposively by considering contextual clues, namely the article titles and sentences containing the keywords. These 140 articles became the corpus with which Corpus Pattern Analysis was conducted. Then, concordances from the computerized corpus were carefully analyzed, using \#LancsBox (Brezina et al., 2018), in order to identify the existing local lexicon or phraseological patterns and collocations which have the same or similar characteristics as those in L1 (Indonesian language) and hence are pertinent to the Indonesian variety of English. The research findings were then presented in the form of contextual information about: (1) loanwords; (2) word meanings; (3) word forms; and (4) collocations. 


\section{FINDINGS AND DISCUSSION}

From the corpus analysis of the newspaper articles, a number of local lexicon or phraseological patterns and collocations were found to be similar to, and perhaps transferred from, L1 (Indonesian language). Since those identified features share much similarity with the linguistic characteristics of Indonesian language, it can be said that they become some sort of indicators of Indonesian variety of English. In this research, those findings were further classified into roughly four groups: (1) Indonesian-origin loanwords; (2) Indonesian English lexicon under semantic shifts; (3) Indonesian English lexicon under morphological shifts; and (4) Indonesian English collocations.

\section{Indonesian-Origin loanwords}

The first aspect that might become the most prominent feature of Indonesian English is loanwords borrowed from L1 (Indonesian). When English is being adopted as a foreign or second language by a community, whether it is the speakers of Indonesian or other languages, it tends to absorb a wide range of vocabulary from their L1. It is all due to the limited vocabulary and concepts that English has so that it often needs to borrow specific lexicon from the new environment where it is used as a foreign or second language in order to explain new things that are nonnative to the English culture. As a result, new varieties of English will always be born whenever it comes into contact with other languages or L1 speakers, characterized by its L1-origin loanwords.

Based on the data analysis, it is found that there are various types of Indonesian-origin loanwords used in the articles compiled in the corpus, all of which belong to noun category. Some examples of those loanwords are nouns denoting: cultures and religions, persons' titles, local foods, and indigenous animals.

\section{Cultures and religions}

In the corpus, as can be seen in Table 1, it was found that most loanwords borrowed from L1 are related to cultures and religions. This study records as many as thirteen Indonesian-origin loanwords for naming various religious holidays and occupations, local musical instruments, traditional performances, armaments, as well as artworks and performance arts.

\section{Table 1}

Loanwords on "Cultures and Religions" and Number of Articles in the Corpus

\begin{tabular}{lc}
\hline Word & Number of Articles \\
\hline "Galungan" & 14 articles \\
"Nyepi" & 48 articles \\
"Waisak" & 21 articles \\
"Idul Fitri" & 260 articles \\
"Idul Adha" & 63 articles \\
"Maulid Nabi" & 15 articles \\
"Imlek" & 65 articles \\
"santri" & 41 articles \\
"angklung" & 47 articles \\
"wayang" & 273 articles \\
"batik" & 284 articles \\
"kris" & 130 articles \\
"gamelan" & 266 articles \\
\hline
\end{tabular}

From the abovementioned list, "batik" became the most frequent lexical item as it was present in 284 articles. "Galungan" on the other hand was the least frequent word, found in only 14 articles. Overall, the loanwords on the list can be categorized based on their different states of borrowing. Some words are already borrowed into standard English and thus included in most English dictionaries. Those words are "batik", "kris", and "gamelan". The second type of loanwords includes those which have similar spellings in other English varieties. Some examples of this type are "Waisak" (Vesak), "Idul Fitri" (Eid al-Fitr), "Idul Adha" (Eid al-Adha), and "Maulid Nabi" (Mawlid). The rest of them, namely "Galungan", "Nyepi”, "Imlek", "santri”, “angklung”, and "wayang", are those which still retain their Indonesian spellings and are borrowed into Indonesian English due to their geo-cultural or religious nature/concept (probably to indicate that the texts deal with Indonesian contexts). The definition and concordance examples of each word are discussed in the following.

\footnotetext{
"Galungan"

- Definition:

The term "Galungan" refers to a holiday in Balinese Hinduism which celebrates the victory of good over evil ("Galungan," 2020). In the corpus, it was found that the word was present a couple of times.

- Examples from concordances: when Hindus in the province prepared for the Galungan celebration, which fell on Sept. 7. The festival prosperity, offered to the Gods on Mount Agung. Galungan on the Island of Gods is a sacred day for the been taking place as Balinese Hindus observed Galungan on Feb. 10. One of the major celebrations in Feb. 10. One of the major celebrations in Bali, Galungan is followed 10 days later by Kuningan, which "Nyepi"

Definition:

"Nyepi" is generally used to denote the "Day of Silence" in Bali ("Nyepi," 2020). That is the day when Balinese people both fast and meditate.
} 
- Examples from concordances:

internet services, we hope Hindus will observe Nyepi solemnly," Darmawan said. Nyepi is a holy day will observe Nyepi solemnly," Darmawan said. Nyepi is a holy day that marks the beginning of the want to tour around and see more of the island, Nyepi will not be much fun as they will not be allowed "Waisak" parade, which will be followed by dinner. On Nyepi day, Amankila has prepared two yoga sessions. At

- Definition:

For Indonesian Buddhist communities, "Waisak" refers to a holiday which marks the birth, enlightenment, and passing of Siddhartha Gautama. The term was derived from the Sanskrit word "Vaisakha" or "Vesakha" (Tracy, 2018).

- Examples from concordances:

Buddha set up at a shopping mall on the eve of Waisak in Surabaya on May 10. Indonesian people Surabaya on May 10. Indonesian people celebrate Waisak, which commemorates the birth and enlightenment

in Magelang, Central Java, to celebrate Tri Suci Waisak or the Buddhist Day of Enlightenment last year. house. "We always have [the open house] every Waisak Day. [We] offer a place for visitors to rest

"Idul Fitri"

- Definition:

"Idul Fitri" is the Indonesian English word for "Eid al-Fitr", one of the biggest holidays for Indonesian Muslims which is celebrated at the end of Ramadan month ("Lebaran," 2020). On that day, most Indonesians return to their hometowns to gather with family members and relatives.

- Examples from concordances:

in Jakarta that serve healthy meals suitable for Idul Fitri. Recently, the eatery opened a new branch in the atmosphere looked similar to that of an Idul Fitri open house. "We always have [the open house] Transportation Ministry and the police. After the Idul Fitri homecoming ritual in June, the Christmas and New "Idul Adha" the implementation of the policy during the Idul Fitri exodus last June, saying it was ineffective and

- Definition:

"Idul Adha" is the Indonesian English term for Eid al-Adha, the Islamic Festival of Sacrifice ("Eid al-Adha," 2020). It is celebrated each year to commemorate God's command to Abraham.

- Examples from concordances:

in qurban (animal sacrifice) during Sunday's Idul Adha in Blitar, East Java, has died following three from carrying out slaughtering activities during Idul Adha. The agency suggested they slaughter the worshippers were following a hadith that stated Idul Adha prayers could be performed after wukuf (peak of

"Maulid Nabi" animals can also be done on the three days after Idul Adha," he said. He said he would sacrifice three cows

- Definition:

"Maulid Nabi" is an Indonesian-origin loanword which refers to the celebration of Prophet Muhammad's birthday ("Maulid Nabi Muhammad," 2020). It consists of two Indonesian words - "Maulid" + "Nabi" — both of which were originally borrowed from Arabic.

- Examples from concordances: the birthday of the Prophet Muhammad, or Maulid Nabi Muhammad, the Sekaten ceremony began with Dipokusumo. "It's a series of commemorations of Maulid Nabi Muhammad and the highlight will be Gerebeg of the birthday of Prophet Muhammad, or Maulid Nabi, royal palaces in Surakarta in Central Java and

"Imlek" to celebrate the birthday of Prophet Muhammad or Maulid Nabi, which fell on Nov. 9, to encourage the public

- Definition:

"Imlek" is an Indonesian word referring to both Chinese New Year and Chinese calendar ("Chinese New Year," 2020).

- Examples from concordances:

only city where Javanese people take part in the Imlek celebration." Surakarta Mayor FX Hadi "Rudy"

Bali, to celebrate Chinese New Year, known as Imlek in Indonesia. The temple was founded in the

to celebrate Chinese New Year, locally known as Imlek, and Cap Go Meh (the 15th day of the first month

lure tourists to destinations that highlighted Imlek and Cap Go Meh celebrations. "We have sold Imlek

"santri"

Definition:

The word "santri" means someone who studies in an Indonesian Islamic boarding school ("Santri," 2020).

- Examples from concordances:

Religious Affairs Lukman Hakim, he called on santri to strengthen Islam and the nation by contributin

to the country in any way they can. Thousands of santri from across Central Java attended the ceremony,

the heritage of our ancestors," said Agung. One santri, 17-year-old Abdul Hamid, said that the game was "angklung"

Livi said. Hopes of the nation: Thousands of santri (Islamic boarding school students) and other

- Definition:

There are various traditional musical instruments from Indonesia. One example from West Java is called "angklung". This instrument is made of bamboo tubes and played by blowing. 
- Examples from concordances:

The Jakarta Post. "I am happy to be able to play angklung, even though this is my first time to play the For the concert, the ministry took along angklung instructors from Saung Udjo in Bandung, West

performers are set to showcase the uniqueness of angklung, a traditional instrument that brings a message residing in Vienna. Aside from enjoying the angklung music performance, the audience was also given

"wayang"

- Definition:

Indonesia is also blessed with innumerable forms of art, some of which have gone global. The theatrical puppet performance called "wayang" has been introduced internationally and given a recognition by UNESCO (Wildan, 2017), making the term quite acceptable to be used in Indonesian English.

- Examples from concordances:

"Jokowi" Widodo has declared Nov. 7 as National Wayang Day. The declaration was made on Dec. 11 during skillfully manipulating buffalo skin to create wayang. Totok said the youth were currently focusing on

a tight shirt to show off his muscular body. "Wayang milenial are new creations that interpret wayang milenial are new creations that interpret wayang with fresh faces to interest children to learn

"batik"

\section{Definition:}

Indonesia is also renowned for its sophisticated tradition of ornamenting and coloring cloth called "batik". The word "batik" itself means a method of drawing patterns on cloth before dying it, or the cloth produced in that way

(Cambridge Dictionary, 2020).

- Examples from concordances:

to his attention to preserving the heritage of batik in the 1970s, a passion he maintained until his

of the 1500s. Dozens of houses here serve as batik stores, workshops where they make the fabric and

said it understood why many still believed that batik in Indonesia was expensive, especially for

process. "Foreign tourists always ask why batik is costly," Gati said. "We have to promote the

"kris"

Definition:

An eminent traditional weapon made in various places in Indonesia is "kris". "Kris" is usually in the form of asymmetrical or wavy dagger. Etymologically, the term was coined from the Old Javanese word "ngiris", meaning "to slice" ("Kris," 2020).

- Examples from concordances:

Wiyata grew up understanding the grandeur of kris. He has a collection of around $100 \mathrm{kris}$ at home. of kris. He has a collection of around $100 \mathrm{kris}$ at home. His children, aged 16 and 14 , initially their boredom when he started talking about kris. However, one day when he showed them a new rare they immediately took a selfie with the kris and proudly posted it on their Instagram

"gamelan"

- Definition:

"Gamelan" is the name of Indonesian set of musical instruments or orchestra originating in Java and Bali. The word has actually been borrowed into English and listed in standard dictionaries such as Cambridge and Oxford Dictionaries.

- Examples from concordances:

began with performances from two sets of gamelan, the Kyai Guntur Madu and Kyai Guntur Sari from

Java. "Sekaten traditionally opens when the gamelan are played," said Kraton head of administration of kinang takes place during the Sekaten gamelan performance. Seven days ahead of the commemoratio Wenten who lives in the United States teaching gamelan music and Balinese dance at a number of

\section{Persons' titles or addressing terms}

Indonesian language differs from English in terms of its more prevalent use of persons' titles and addressing terms. When addressing an adult, particularly someone older or superior, Indonesians tend to use titles or addressing terms, even though they might know each other very well. This behavior is often adopted in their use of English as shown by the following loanwords found in the corpus (see Table 2). Out of the four honorific titles above, two of them are originally derived from Indonesian kinship terms, namely "Bu" from "ibu" (mother) and "Pak" from "bapak" (father).
Table 2

Loanwords on "Persons' Titles or Addressing Terms" and Number of Articles in the Corpus

\begin{tabular}{lc}
\hline Word & Number of Articles \\
\hline "Bu" & 78 articles \\
"Pak" & 285 articles \\
"Kiai" (or "Kyai") & 65 articles \\
"Haji" & 107 articles \\
\hline
\end{tabular}

The other two are religious titles which are usually used in the Islamic register. The details of each term are explicated below.

\section{"Bu"}

Definition:

The word "Bu" is a title used in front of the name of a woman. It is an Indonesian English equivalent for "Ms" or "Mrs". In many Indonesian contexts, it is impolite to address a woman with only her name, especially when she is older, higher in social position, or unfamiliar to the speaker. Therefore, it is unsurprising to hear Indonesians always employ titles to address other people, even when they speak or write in English. 
- Examples from concordances:

take notes. "[After the class ended], I phoned Bu Toety, telling her that I wanted to study," she

"Ahok chose the flowers himself because they are Bu Vero's favorite," Neneng said on Thursday,

in a male-dominated environment. Question: Bu Susi, you're a minister in a field dominated by

estaurant, Ikan Bakar Cianjur seafood restaurant, Bu Endang Javanese restaurant as well as the

"Pak"

Definition:

The male version of the title "Bu" is "Pak". In other words, "Pak" is a title used in front of a man's name. The English equivalent for the term is "Mr". As mentioned earlier, "Bu" and "Pak" are used by Indonesians to show respect to the person they are speaking or writing to.

- Examples from concordances:

I am hoping for the one who sits beside me, Pak Jokowi." The statement was met with applause.

rongdoing. "If [people] throw accusations against Pak SBY saying he sponsored and funded the Nov. 4

evil slander but also an extraordinary insult to Pak SBY," she wrote, referring to Yudhoyono by his

"Kiai" (or "Kyai")

processed [the purchase of film rights] since Pak Syamsul had attended the [film's] gala premiere.

Definition:

In the country's Islamic tradition, there is one honorific that is very popular and always used for addressing religious leaders and experts who also own or run their Islamic boarding schools. Those heads of boarding schools are called "Kiai" (or "Kyai"). The term was originally a Javanese word which has been used to refer to countless prominent figures in the development of Islam in Indonesia ("Kyai," 2020).

- Examples from concordances:

[to radicalism]," she said. "I have asked the kiai, my seniors, 'Are mosques a place to express

The party gave a special award to Mbah Sahal, or Kiai Sahal as he was affectionately called within NU, Maslakul Huda boarding school from his father, Kiai Mahfudz Salam, in 1963. He was known for Saka Tunggal Mosque imam and local figure Kiai Sulam said they celebrated the Islamic holiday

"Haji"

Definition:

"Haji" is the Indonesian English equivalent for "Hajji", a title for those who have completed the Hajj to Mecca. In practice, some people attach the honorific to their names to indicate status. It is very common to see Indonesians calling somebody's name using the title "Haji" in order to show their respect to the person and his/her religious endeavor.

- Examples from concordances:

summit. Karim's body was never found. His widow, Haji Parveen, said she tried her best to dissuade him in Tana Beru, Bulukumba, South Sulawesi, by Haji Ully, a well known crafter of phinisi, Indonesia' from Uttar Pradesh in India in 1956. His father, Haji Mohamed Mustafa, had come to the country four Indonesian novel of the same title penned by Haji Abdul Malik Karim Amrullah, who is better known

\section{Local foods}

As shown in Table 3, one of the most productive sources of loanwords in English and many other languages is food names. In every area there are always unique and distinctive foods whose names cannot simply be translated into another language. It shows that food reflects and constitutes an essential part of culture.

Indonesia is rich in cuisines and traditional foods. Many of its foods have been well introduced abroad, while many others are still exclusive to the local communities. Some local food terms that can be identified in the corpus are "tempeh", "tumpeng", "rendang", and "rawon".

\section{Table 3}

Loanwords on "Local Foods" and Number of Articles in the Corpus

\begin{tabular}{lc}
\hline Word & Number of Articles \\
\hline "tempeh" & 95 articles \\
"tumpeng" & 59 articles \\
"rendang" & 126 articles \\
"rawon" & 18 articles \\
\hline
\end{tabular}

Based on the above-mentioned table, "rendang" seemed to be the most popular food term which was used in the Indonesian English discourse and talked about in 126 articles. Contrariwise, "rawon" was the least used term discussed in only 18 articles.

"tempeh"

Definition:

"Tempeh" (also spelled "tempe") is a traditional soy food high in protein from Indonesia made through the process of culturing and fermentation. Due to its high nutritional value, "tempeh" is very popular among vegetarians and vegans as a meat replacement (Link, 2017). Although it has been known in many other countries, "tempeh" comes originally from and is still ubiquitously produced in Indonesia. The name "tempeh" itself is said to be invented from the Old Javanese "tumpi" (a name of food which resembles "tempeh" in color), or the local word "tape/tapai" which literally means "fermentation" (Isnaeni, 2014). 


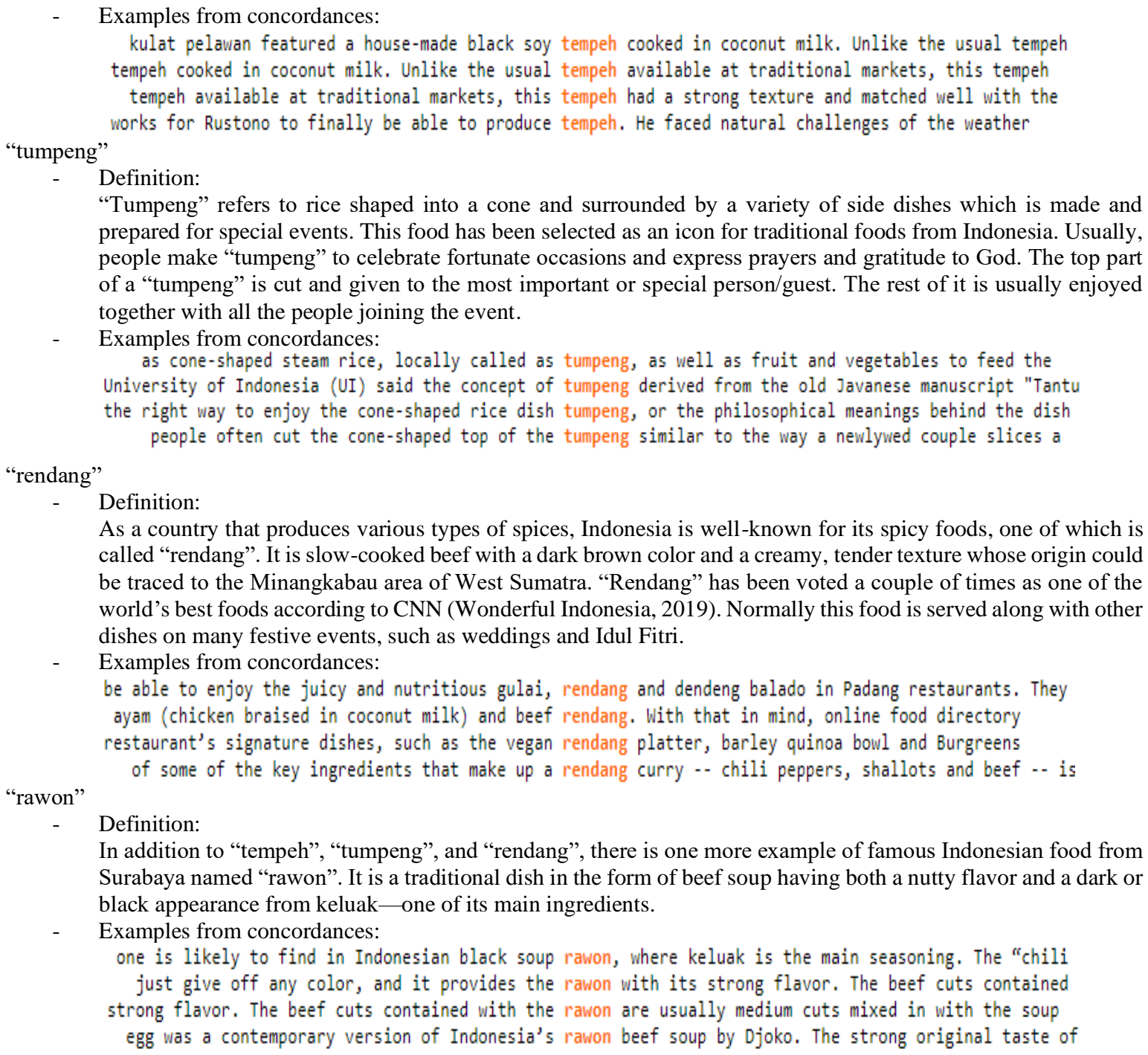

\section{Indigenous animals}

Another aspect which is also observed to trigger borrowing in Indonesian English is names of indigenous animals (see Table 4). Being one of the largest archipelagic states in the world, Indonesia is inhabited by a wide variety of unique animals. The uniqueness of those animals make them known by the world through their Indonesian names, often because they are untranslatable or unknown to English speaking societies which are often referred to as Kachru's inner circle.

There are three Indonesian-origin loanwords for naming animals identified in the corpus, namely "babirusa", "komodo", and "orangutan". Based on their frequencies of occurrence, both "komodo" and "orangutan" were used much more often than "babirusa" in the corpus.

"babirusa"

The first example of animal names which might characterize the use of Indonesian English is "babirusa". The term was coined from the combination of two Indonesian words: "babi" + "rusa". The word "babi" in Indonesian language means "pig", while "rusa" means "deer". "Babirusa" itself refers to an animal from the swine family that is identified by its long upper and lower canines resembling deer horns. It is indigenous to Sulawesi and some nearby areas.
Table 4

Loanwords on "Indigenous Animals" and Number of Articles in the Corpus

\begin{tabular}{lc}
\hline Word & Number of Articles \\
\hline "babirusa" & 4 articles \\
"komodo" & 245 articles \\
"orangutan" & 144 articles \\
\hline
\end{tabular}

Quick searches in Cambridge Dictionary (2020) and Oxford Learner's Dictionaries (2020) showed that the words "komodo" and "orangutan" have already been included in the standard English lexicon. In contrast, the term "babirusa" has not been listed in the two dictionaries, and this is possibly the reason why it was less frequently used than the previous two terms. Detailed descriptions of the three loanwords are presented as follows: 


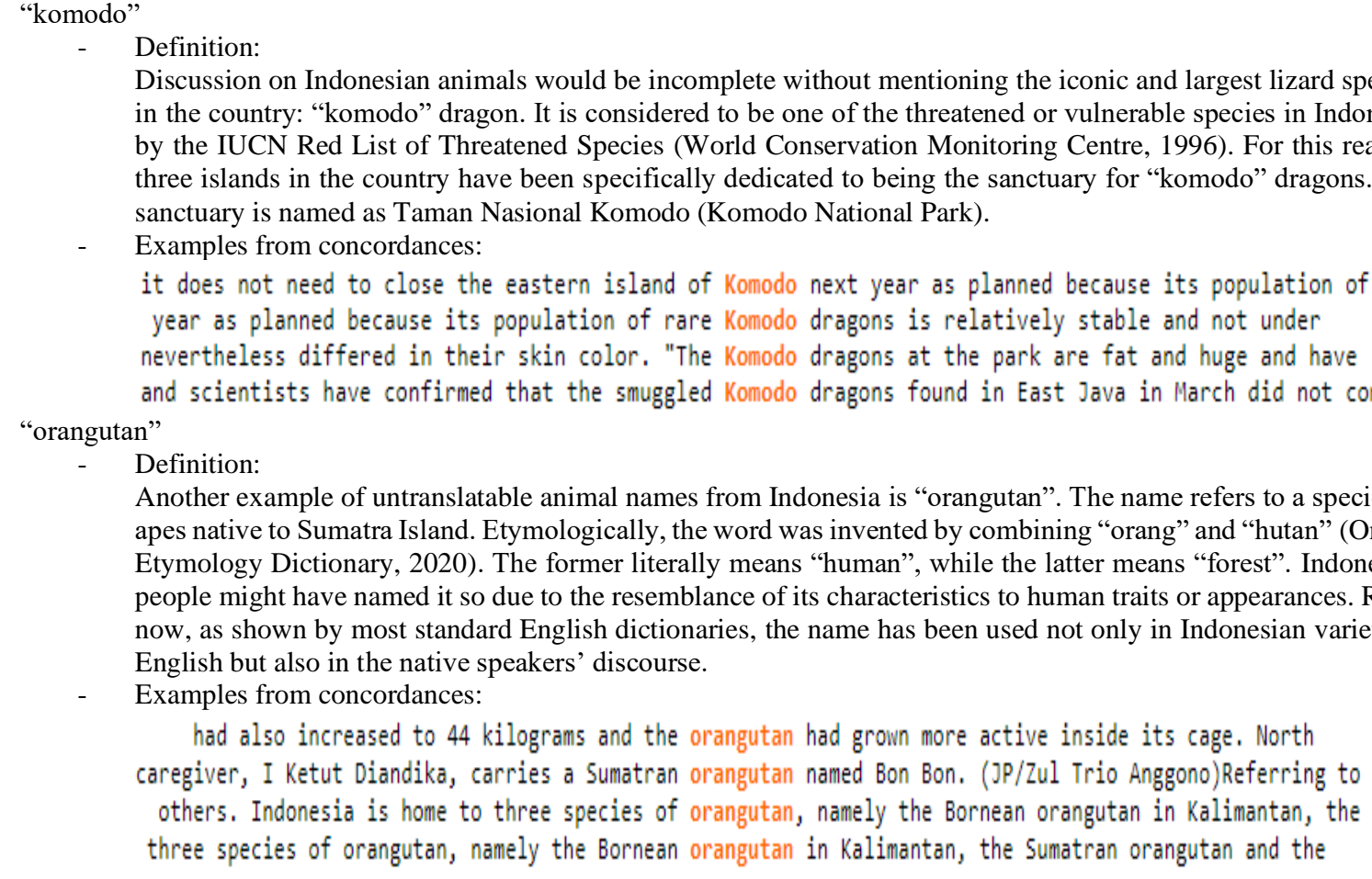

\section{Indonesian English lexicon: Semantic shifts}

The second aspect that characterizes the Indonesian variety of English in the corpus data is the writers' different use of certain English words by slightly changing their meaning. This type of phenomenon is often referred to as semantic shift. In the case of Indonesian English, it seems that the semantic shifts are mainly caused by the use of similar words in the writers' L1. An example of the lexical items undergoing semantic shifts found in the corpus is "terminal", which is occurred in 54 articles.

According to Cambridge Dictionary (2020), a terminal is used to refer to a part of a station, port, or airport. In some of the concordances, there are instances where "terminal" is collocated with the word "bus". Those concordances are:

\footnotetext{
and much more." In addition to the RPTRA, the bus terminal plans to improve its infrastructure and

to ensure service quality at the Pulo Gebang bus terminal was in accordance with regulations. Besides seen waiting for passengers at the Pasar Minggu bus terminal in South Jakarta on Thursday morning, amid a regional administrations, Jatijajar is a type $\mathrm{A}$ bus terminal, which the central government administers.
}

In most varieties of English, there is another word that collocates with "bus" much more often than the word "terminal", and that is the word "station". As defined by Cambridge Dictionary (2020), a station is a place where trains or buses stop which usually consists of a building and the area surrounding it. Thus, most English speakers would tend to use the phrase "bus station" instead of "bus terminal" to indicate the whole bus-area (not only a particular building). However, the Indonesian English's preference for "bus terminal" over the phrase "bus station" is not for no reason. It is actually a result of L1 influence. In Indonesian language, people would use the word "terminal" to indicate the whole area of a bus station, and that L1 meaning might have been carried over into their English variety.
Indonesian English lexicon: Morphological shifts

In addition to semantic shifts, when Indonesians adopt English to be their foreign or second language, they also tend to transfer their L1 morphological features to their L2. This phenomenon is hence called morphological shift. It basically is when the writers use English words differently by slightly changing their forms. One example of morphological-shift cases identified in the corpus was the use of the word staff as a countable noun denoting "a person" instead of "a group of people".

In their L1, Indonesians perceive the word "staff" to be a countable noun meaning "a person who works for an organization". Standard English on the other hand defines the word as an uncountable noun which means "a group of persons" (Table 5). 
Table 5

Indonesian English Lexicon under Morphological Shift and Number of Articles in the Corpus

\begin{tabular}{lc}
\hline Word & Number of Articles \\
\hline "a staff" & 4 articles \\
"staffs" & 8 articles \\
\hline
\end{tabular}

Here are some concordances which demonstrate few morphological shifts in the corpus data that distinguish Indonesian English from the varieties of English in Kachru's inner circle:

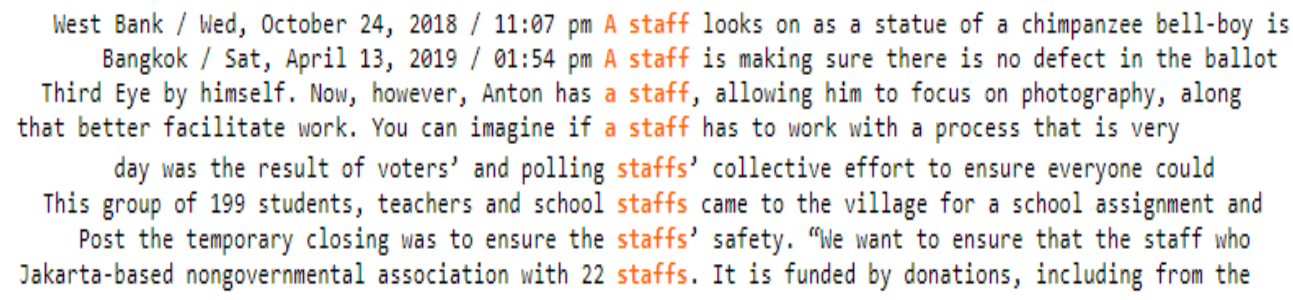

From those two concordances, it can be concluded that the writers tend to conceptualize the lexical item "staff" as a countable noun. It can be seen from the singular and plural forms of the word in their sentences. As mentioned earlier, in Indonesian language, the translation of "staff" always functions as a countable noun which means either "a person" (a staff) or "persons" (staffs). Therefore, those writers might have transferred that morphological rule of countable nouns to a word that is actually considered a "group noun" by most varieties of English. As stated by Cambridge Dictionary (2020), "staff" means "the group of people who work for an organization". Indonesian English in this case might surprisingly follow Indian English in the sense that it defines the word as "a person who works for an organization" (Cambridge Dictionary, 2020).

\section{Indonesian English collocations}

Before talking about collocations of a new variety of English, this study tries to free itself from linguistic prescriptivism which suggests that only native-like or inner circle grammar and collocations are right. It seeks to be open to any possible collocations that might have previously been considered inaccurate by the so-called native speakers and therefore adopts a descriptive approach to its linguistic analysis. It tries to understand that every lexicon in every language has its own patterns of collocations, and that a new variety of English might be born as a hybrid form that combines the patterns of collocations of both L1 and L2.

In conducting the analysis, the researcher first compared collocational patterns in standard English and Indonesian language. In standard English varieties, the preposition "about", prescriptively speaking, does not commonly collocate with certain verbs, such as "discuss" and "explain" (Cambridge Dictionary, 2020). In Indonesian language, on the other hand, the preposition "tentang" (about) seems to pervasively collocate with various verbs, including both "menjelaskan" (explain) and "berdiskusi" (discuss). As depicted in Table 6, two examples of English collocational patterns identified in the corpus that might have occurred as a result of linguistic transfers of the above-mentioned verb-preposition behaviors in Indonesian language are "discuss about" and "explain about".

Table 6

Indonesian English Collocations and Number of Articles in the Corpus

\begin{tabular}{lc}
\hline Word & Number of Articles \\
\hline "discuss about" & 6 articles \\
"explain about" & 9 articles \\
\hline
\end{tabular}

The following sample of concordance lines shows how the Indonesian English structure of "discuss about" deviates a little bit from the standard norms.

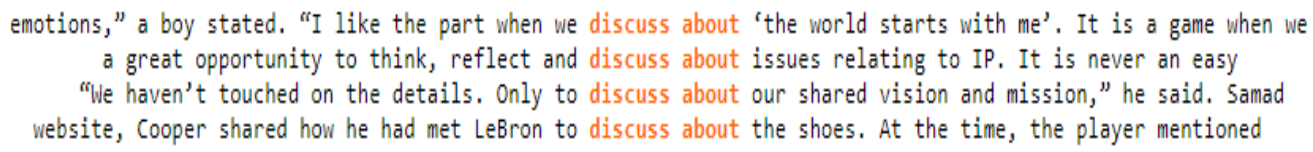

Prescriptively speaking, the pattern "discuss + about" is inaccurate in the standard English. As mentioned in Oxford Advanced Learner's Dictionary (2020), most people, teachers and exams still consider the use of "about" after the intransitive verb "discuss" to be incorrect. In Indonesian language on the other hand, people would tend to say a literal translation of "discuss about something" instead of "discuss something". As a result, this pattern seems likely to be carried over into their Indonesian English.
Another similar pattern which might also be indicative of Indonesian English is the phrase "explain about". Indonesian translation of the verb "explain" is "menjelaskan", and it is frequently followed by the Indonesian preposition "tentang" (about). Therefore, it is very common to hear Indonesians say "explain about" due to their L1 influence. Here are some concordances containing the phrase: 


\begin{abstract}
and the spooky myths that surround them. "We explain about several mystical or haunted places in Bandung tax is still not well-known so we would like to explain about it using leaflets provided by the city," its peace, I think it would not be wrong for me to explain about my family and the life principles I taught them.

to face Sandiaga on Sunday. He said he would explain about the planned pre-employment card in the debate.
\end{abstract}

\section{CONCLUSION}

In agreement with the findings of this study, it can be inferred that a new variety of English might or tends to be born when this language is adopted as a medium of communication among people of the same community to express their shared identity and local issues, regardless of its EFL or ESL status. The data analysis shows that the inclination toward an Indonesian variety of English used in the corpus is indicated by the pervasive Indonesian-origin loanwords denoting concepts that are new to the language, such as cultures and religions, persons' titles, local foods, and indigenous animals. Besides the use of loanwords, the inclination is also characterized by the Indonesian English lexicon shaped by semantic shifts and morphological shifts, as well as collocational patterns driven by the influence of L1.

Even though the characteristics of Indonesian English in the lexical level shown by the data of this research were quite conspicuous, this study still lacks information about how the variety might exist or has grown in a broader sense and from different modes. For that reason, more in-depth and comprehensive research is needed to provide better understanding of both written and spoken forms of Indonesian English through various levels of analyses. With such findings, it may also open up further pedagogical debates on whether English teachers in Indonesia should stick with the prescriptive ways of teaching by dictating the correct forms of English to learn, or embrace a more descriptive approach which reflects the bilingual or even multilingual nature of most English speakers/learners in the country. Intelligibility and how "acceptable" those features of Indonesian English are to be integrated into instructions are of course other concerns which demand further inquiries that may help to build up an ideal picture of English-as-a-lingua-franca approach to Indonesia's ELT.

\section{REFERENCES}

Alwi, H., \& Sugono, D. (Eds.). (2011). Politik bahasa: Rumusan seminar politik bahasa. Badan Pengembangan dan Pembinaan Bahasa.

Asimonoff. (2014, July 19). Indonesia: An overview of people, culture, and traditions. Retrieved April 4, 2020, from

https://blogs.transparent.com/indonesian/indonesi a-people-culture-and-traditions/

Berardo, S. (2011). New Englishes in a new world: A brief introduction to Canadian English. Retrieved from

https://www.researchgate.net/publication/266558 847_New_Englishes_in_a_New_World_A_Brief _Introduction_to_Canadian_English
Brezina, V., Timperley, M., \& McEnery, T. (2018). \#LancsBox v. 4.x [software]. Available at: http://corpora.lancs.ac.uk/lancsbox

British Council Serbia. (2013, December 14). David Crystal - Will English always be the global language? [Video File]. Retrieved from https://www.youtube.com/watch?v=5Kvs8SxN8 mc

Cambridge Dictionary. (2020). Cambridge Dictionary. Retrieved January 1, 2020, from https://dictionary.cambridge.org/

Chinese New Year. (n.d.). In Wikipedia. Retrieved January 10, 2020, from https://en.wikipedia.org/wiki/Chinese_New_Year

Civinini, C. (2019, August 28). Sustained growth for the international schools' sector - ISC. Retrieved April 26, 2020, from https://thepienews.com/news/sustained-growthinternational-schools-sector-isc/

Dardjowidjojo, S. (2003). The role of English in Indonesia: A dilemma. In K. E. Sukamto (Ed.), Rampai Bahasa, Pendidikan, dan Budaya: Kumpulan Esai Soenjono Dardjowidjojo, (pp. 4150). Yayasan Obor Indonesia.

Dewi, I. I., Winiharti, M., \& Prawati, M. T. (2018). The study of Indolish - Indonesian English variety: Is it understood globally? International Journal of Humanities and Social Science Invention, 7(8), 27-34. http://www.ijhssi.org/papers/vol7(8)/Version3/E0708032734.pdf

Eid al-Adha. (n.d.). In Wikipedia. Retrieved January 10, 2020, from https://en.wikipedia.org/wiki/Eid_al-Adha

Endarto, I. T. (2018). Indonesian English(?): A corpusbased lexical analysis. Journal of Modern Languages, 28, 44-52. https://jml.um.edu.my/article/view/13187/9458

Galungan. (n.d.). In Wikipedia. Retrieved January 10, 2020, from https://en.wikipedia.org/wiki/Galungan.

Google. (2013). Google Books Ngram Viewer. Retrieved April 27, 2020 from https://books.google.com/ngrams

Gur, W. (2009, December 3). Bahasa Indolish. Retrieved December 1, 2019, from https://www.bahasakita.com/id/bahasbahasa/bahasa-indolish/

Hanks, P. (2009). Corpus pattern analysis. Retrieved from https://www.researchgate.net/publication/228574 527_Corpus_pattern_analysis

Isnaeni, H. F. (2014, July 9). Sejarah tempe. Retrieved January 8, 2020, from https://historia.id/kultur/articles/sejarah-tempevX7XD

Jenkins, J. (2000). The phonology of English as an international language. Oxford University Press. 
Kachru, B. B. (1992). The other tongue: English across cultures (2nd Ed.). University of Illinois Press.

Kachru, Y. \& Nelson, C. L. (2006). World Englishes in Asian contexts. Hong Kong University Press.

Kirkpatrick, A. (2007). World Englishes: Implications for international communication and English language teaching. Cambridge University Press.

Kirkpatrick, A. (2012). English as an international language in Asia: Implications for language education. In A. Kirkpatrick and R. Sussex (Eds). English as an international language in Asia: Implications for language education. Springer.

Kris. (n.d.). In Wikipedia. Retrieved January 10, 2020, from https://en.wikipedia.org/wiki/Kris.

Kyai. (n.d.). In Wikipedia. Retrieved January 10, 2020, from https://en.wikipedia.org/wiki/Kyai

Lauder, A. (2008). The status and function of English in Indonesia: A review of key factors. Makar, Sosial Humaniora, 12(1), 9-20. http://repository.ui.ac.id/contents/koleksi/2/21ff5 564b83214c97aa449dd0155b09d142cf454.pdf

Lebaran. (n.d.). In Wikipedia. Retrieved January 10, 2020, from https://en.wikipedia.org/wiki/Lebaran

Lie, A. (2017). English and identity in multicultural contexts: Issues, challenges and opportunities. TEFLIN Journal, 28(1), 71-92. http://dx.doi.org/10.15639/teflinjournal.v28i1/7192

Link, R. (2017, May 11). Why tempeh is incredibly healthy and nutritious. Retrieved January 8, 2020, from https://www.healthline.com/nutrition/tempeh

Martin, N. (2016, February 6). English in Indonesia: Is it still a matter of British or American? Retrieved September 5, 2019, from

https://www.thejakartapost.com/news/2016/02/06 /english-indonesia-is-it-still-a-matter-british-oramerican.html

Maulid Nabi Muhammad. (n.d.). In Wikipedia. Retrieved January 10, 2020, from https://id.wikipedia.org/wiki/Maulid_Nabi_Muha mmad

Muhammad, W. A. (2015, June 25). Indolish. Retrieved September 5, 2019, from https://www.kompasiana.com/wahyudiakmaliah muhammad/5510ecd3813311d334bc759a/Indolis $\mathrm{h}$

Nyepi. (n.d.). In Wikipedia. Retrieved January 10, 2020, from https://en.wikipedia.org/wiki/Nyepi

Online Etymology Dictionary. (2020). Online Etymology Dictionary. Retrieved January 10, 2020, from https://www.etymonline.com/

Oxford Advanced Learner's Dictionary. (2020). Oxford Learner's Dictionaries. Retrieved January 10, 2020, from https://www.oxfordlearnersdictionaries.com/defin ition/english/discuss

Oxford Learner's Dictionaries. (2020). Oxford Learner's Dictionaries. Retrieved January 1, 2020, from https://www.oxfordlearnersdictionaries.com/
Poblete, B., Garcia, R., Mendoza, M., \& Jaimes, A. (2011). Do all birds tweet the same? Characterizing Twitter around the world. Proceedings of the 20th ACM International Conference on Information and Knowledge Management, 1025-1030.

Rautionaho, P., Deshors, S. C., \& Meriläinen, L. (2018). Revisiting the ENL-ESL-EFL continuum: A multifactorial approach to grammatical aspect in spoken Englishes. ICAME Journal, 42(1), 4178. https://doi.org/10.1515/icame-2018-0004

Rini, J. E. (2014). English in Indonesia. Beyond Words, 2(2), 19-39. http://journal.wima.ac.id/index.php/BW/article/d ownload/591/654

Santri. (n.d.). In Wikipedia. Retrieved January 10, 2020, from https://en.wikipedia.org/wiki/Santri

Stockton, R. J. (2018). Recultured language in Indonesian English language teaching. Indonesian Journal of English Language Teaching, 13(2), October 2018, 131-153. https://www.researchgate.net/publication/330983 458_Recultured_language_in_Indonesian_Englis h_Language_Teaching/link/5c5ea10045851582c 3d8aa66/download

Tracy, M. (2018, May 24). 9 fakta soal waisak yang harus kamu tahu. Retrieved January 1, 2020, from https://www.pegipegi.com/travel/9-faktasoal-waisak-yang-harus-kamu-tahu/

Wildan, M. (2017, January 26). Pertunjukan wayang (the wayang puppet theatre)-sebagai ICH LIST UNESCO dari Indonesia. Retrieved January 10, 2020, from https://kebudayaan.kemdikbud.go.id/ditwdb/pertu njukan-wayang-the-wayang-puppet-theatresebagai-ich-list-unesco-dari-indonesia/

Wonderful Indonesia. (2019, September 12). Once again! Indonesia's RENDANG and NASI GORENG crowned world's best foods. Retrieved January 11, 2020, from https://www.indonesia.travel/gb/en/news/onceagain-indonesia-s-rendang-and-nasi-gorengcrowned-world-s-best-foods

World Conservation Monitoring Centre. (1996, August 01). Varanus komodoensis. The IUCN red list of threatened species. Retrieved January 11, 2020, from https://dx.doi.org/10.2305/IUCN.UK.1996.RLTS .T22884A9396736.en

NOTE:

All the corpus data (concordance lines) presented in this study were compiled from

http://www.thejakartapost.com/. 